\title{
Datasets for research on groundwater flow and its interactions with surface water in an alpine catchment on the northeastern Tibetan Plateau,
}

\section{China}

Zhao Pan ${ }^{1}$, Rui Ma ${ }^{1 *}$, Ziyong Sun ${ }^{1}$, Yalu Hu${ }^{1}$, Qixin Chang ${ }^{2}$, Mengyan Ge ${ }^{1}$, Shuo Wang ${ }^{1}$, Jianwei Bu ${ }^{1}$,

5 Xiang Long ${ }^{1}$, Yanxi Pan ${ }^{1}$, and Lusong Zhao ${ }^{1}$

1 Hubei Key Laboratory of Yangtze River Basin Environmental Aquatic Science, School of Environmental Studies, and State Key Laboratory of Biogeology and Environmental Geology, China University of Geosciences, Wuhan 430078, China

2 College of Environment and Civil Engineering, Chengdu University of Technology, Chengdu 610059, 10 China

Correspondence to: Rui Ma (rma@cug.edu.cn)

Abstract. Climate warming has significantly changed the hydrological cycle in cold regions, especially in areas with distributed permafrost. Groundwater flow and its interactions with surface water are important components of the hydrological process; however, few studies or modeling works have been based on long-term groundwater level, temperature, hydrogeochemistry or isotopic field observations from boreholes due to obstacles such as remote locations, limited infrastructure, and harsh work conditions. In the Hulugou catchment located in the headwater region of the Heihe River on the northeastern Tibetan Plateau (TP), we drilled four sets of depth-specific wells and monitored the dynamic groundwater levels and temperatures at different depths. Surface water (including river water, glacier meltwater, and snow meltwater), precipitation, groundwater from boreholes, spring water, and soil water samples were collected to measure the hydrochemistry, dissolved organic carbon (DOC), dissolved inorganic carbon (DIC), and stable and radioactive isotopes at 64 sites. This study provides datasets of these groundwater parameters spanning six consecutive years of monitoring/measurements. These data can be used to investigate the groundwater flow process and the interactions between groundwater and 
surface water on the TP under global climate change. The datasets provided in this paper can be obtained at https://doi.org/10.5281/zenodo.5184470 (Ma et al., 2021b) and will be subject to further updates.

\section{Introduction}

As the "Third Pole" of the Earth, the Tibetan Plateau (TP) is known as the "Water Tower of Asia" and comprises the headwater regions of many large rivers in Asia, including the Linsang, Ganges, Indus, Yellow and Yangtze Rivers (Qiu, 2008; Immerzeel et al., 2010). At present, the total amount of water storage on the TP (including glacier reserves, lake water, and runoff from the outlets of major rivers) has been initially estimated to exceed nine trillion cubic meters (Li et al., 2019; Pritchard, 2019; Liu et al., 2020). Under the background of global warming, not only has the temperature of the TP gradually increased over the past 50 years (Hartmann et al., 2013; Yao et al., 2013), but the warming rate has also been slowly increasing (Chen et al., 2015; Kuang and Jiao, 2016). Therefore, the TP has been experiencing a series of remarkable changes, such as permafrost degradation, continuously decreasing snow cover, and glacier and lake shrinkage (Jin et al., 2011; Yao et al., 2012; Liu et al., 2015; Huang et al., 2017; Xu et al., 2017; Bibi et al., 2018; Ran et al., 2018; Yao et al., 2019b; Bian et al., 2020). These changes have vastly impacted the hydrological system on the TP, affected the living environments of 1.7 billion people and caused economic losses of up to $\$ 12.7$ trillion (Yao et al., 2019a).

The flow of groundwater and its interaction with surface water play important roles in regional ecological-environmental and biogeochemical cycles, especially in cold regions (Frey and Mcclelland, 2009; Prowse and Brown, 2010; Wang et al., 2010; Amanambu et al., 2020). Previous studies have shown that groundwater, the main recharge source of river water in permafrost regions, is an important component in maintaining the base flow of rivers (Walvoord et al., 2012; Carey et al., 2013; Ma et al., 2017; Evans et al., 2020; Ma et al., 2021a; Wang et al., 2021). Some studies have suggested that increased groundwater temperatures caused by increased air temperatures adversely affect the biogeochemical process of groundwater, resulting in a decline in groundwater quality and thus affecting the use of 
resources (Green et al., 2011; O'donnell et al., 2012; Sharma et al., 2012; Cochand et al., 2019). In the case of global warming, interactions between groundwater flow and surface water may cause the release of carbon trapped in permafrost and aggravate the greenhouse effect (Harlan, 1973; Solomon et al., 2007; Schaefer et al., 2011; Wisser et al., 2011; Mckenzie and Voss, 2013; Connolly et al., 2020; Behnke et al., 2021). Because of the heat released by the movement of groundwater in the subsurface layer and the thermal insulation effect of the surface ice layer, saturated sediments are not frozen year round and provide interstitial habitats for groundwater fauna (Schohl and Ettema, 1990; Clark and Lauriol, 1997; Alekseyev, 2015; Huryn et al., 2020; Terry et al., 2020). All these findings undoubtedly confirm the importance of groundwater flow in cold-region hydrological systems.

However, existing studies on the interactions between groundwater and surface water have mainly focused on Arctic-subarctic regions. These areas are mainly characterized by continuous permafrost, and the main groundwater recharge source in these regions is in the form of spring snowmelt (Mcclymont et al., 2010). In contrast to Arctic-subarctic regions, the middle- and low-latitude catchments on the TP feature distributions of continuous permafrost, discontinuous permafrost, island permafrost and seasonally frozen ground due to the great topographical and elevational differences that exist throughout the region (Cheng and Jin, 2013; Chang et al., 2018). The Asian monsoon climate on the TP causes the main hydrological inputs to occur in summer and autumn, when the amounts of precipitation and glacier meltwater are largest ( $\mathrm{Lu}$ et al., 2004; Chang et al., 2018). Different combinations of permafrost, seasonally frozen ground and hydrological conditions lead to complex interactions between groundwater and surface water on the TP (Woo, 2012). Therefore, it is necessary to deepen the research on groundwater flow processes on the TP.

Current studies on the interactions between groundwater and surface water on the TP have focused on tracing flow paths with different types of isotopic and geochemical data or building numerical waterheat coupling models to explore the influence of climate change on hydrological processes (Ma et al., 2009; Ge et al., 2011; Evans et al., 2015; Hu et al., 2019; Li et al., 2020a; Yang and Wang, 2020; Tan et 
al., 2021). Although great progress has been made in studying hydrological processes on the TP, including research on changing streamflow compositions under the impact of climate change and frozen soil degradation (Wang et al., 2018; Cuo et al., 2019; Xu et al., 2019; Shen et al., 2020), little is known about the groundwater system or the processes that control groundwater and surface water interactions due to challenges associated with the poor field conditions and weak infrastructure on the TP (Yao et al., 2019a). Most existing studies have used spring water and baseflow measurements in winter to represent groundwater and have rarely directly observed groundwater indicators through boreholes (Pu et al., 2017; Gui et al., 2019; Li et al., 2020b; Pu et al., 2021). The coupled groundwater flow and heat transport models employed in previous studies to represent permafrost regions on the TP have mainly focused on scenarios in which the conceptual models are tested and lack verification with actual field data (Ge et al., 2011; Evans et al., 2015). To date, there is no established systematic research site considering groundwater flow or its interactions with surface water on the TP to monitor physical or chemical surface water and groundwater indicators and the freeze-thaw processes of permafrost and seasonally frozen ground. To fill this gap, we established a systematic monitoring site in the upper reaches of the Heihe River on the northeastern TP.

Specifically, this paper introduces a monitoring system for the groundwater level, ground temperature, water chemistry, dissolved organic carbon (DOC) and dissolved inorganic carbon (DIC) concentrations, and isotopic compositions of various water bodies in an alpine catchment. In Section 2, the general setting of the study area is introduced in detail. In Section 3, the layout of the monitoring wells, the lithology of the boreholes and the mineralogical compositions of the cores are described. In addition, groundwater level and ground temperature changes are also explained. In Section 4, the methods used for the collection, preservation, and analysis of data representing various water bodies are described. The methods for obtaining raw data mentioned in this article are provided in Section 5, and future research prospects and a summary of the whole article are provided in Section 6. 


\section{Study area}

The study area is located in the upper reaches of the Heihe River in the northeastern region of the Tibetan Plateau (Fig. 1). The catchment occupies an area of $23.1 \mathrm{~km}^{2}\left(99^{\circ} 50^{\prime} 37^{\prime \prime}-99^{\circ} 53^{\prime} 54^{\prime \prime} \mathrm{E}\right.$ and $\left.38^{\circ} 12^{\prime} 14^{\prime \prime}-38^{\circ} 16^{\prime} 23^{\prime \prime} \mathrm{N}\right)$. The elevation of the study area ranges from 2960 to $4800 \mathrm{~m}$ a.s.l. The study area has a continental climate, with warm, humid summers and cold, dry winters. The annual average temperature is $-3.1{ }^{\circ} \mathrm{C}$, and the annual precipitation is $403.4 \mathrm{~mm}$; precipitation is mainly concentrated from July to September, with these months accounting for approximately $70 \%$ of the annual precipitation (Chen et al., 2014a; Chen et al., 2014b). The water surface evaporation was $1231 \mathrm{~mm}$ in 2013 (Yang et al., 2013). The discharge of the catchment was approximately $3.58 \times 10^{4} \mathrm{~m}^{3} /$ day in 2012 (Chen et al., 2014a; Chen et al., 2014b). The latest specific precipitation data, temperature data and discharge data can be downloaded from the following website: http://hhsy.casnw.net.

Two main tributaries originate from the southern glaciers in the study area (Fig. 1). These tributaries are mainly fed by glacier and snow meltwater, ice lakes and springs in the high mountains (Yang et al., 2013; Chang et al., 2018; Hu et al., 2019). In the warm season of each year (May-September), these tributaries are sustained; during the rest of the year, they are intermittently dry (Yang et al., 2013; Chang et al., 2018; Hu et al., 2019). The two tributaries converge into a single channel at the northern end of a piedmont alluvial plain and finally flow into the main channel of the Heihe River. Due to the thick alluvialpluvial sediments deposited in this plain, groundwater and surface water interact significantly (Ma et al., 2017; Chang et al., 2018; Hu et al., 2019).

The region above $4200 \mathrm{~m}$ a.s.l. in the study area is mainly eroded by mountain glaciers. The area comprising modern glaciers and permanent snow cover is approximately $1.62 \mathrm{~km}^{2}$ (Ma et al., 2017; Chang et al., 2018; Hu et al., 2019). Many moraine sediments are distributed on the surface in this region, constituting a porous aquifer of moraine breccia with large pores and good connectivity (Chang et al., 2018). According to field investigations, the aquifer exhibits high permeability and provides a good 
channel for groundwater flow (Ma et al., 2017; Chang et al., 2018). In the warm season (May-September), the aquifer is recharged by meltwater from glaciers and snow and by precipitation; this water is rapidly discharged to nearby rivers and provides lateral recharge for low-elevation aquifers (Ma et al., 2017). Vegetation is rare in this region, and the vegetation coverage is extremely low (Liu et al., 2012, 2014).

In the elevation range of 3500 to $4200 \mathrm{~m}$ a.s.1., permafrost is distributed discontinuously and reaches a maximum melting depth of $2 \mathrm{~m}$ at the end of August (Ma et al., 2017). Through analysis of drilling data, the thickness of permafrost was found to be approximately $20 \mathrm{~m}$ (Ma et al., 2017; Hu et al., 2019). There is a porous aquifer consisting of argillaceous gravel on the planation surface at the top of the hill in the permafrost region (Ma et al., 2021a). In the warm season (May-September), the groundwater in this aquifer is mainly recharged by the infiltration of glacier and snow meltwater, precipitation, and groundwater from the higher-elevation aquifer and exists in the forms of suprapermafrost, intrapermafrost, and subpermafrost groundwater (Ma et al., 2021a). This aquifer groundwater is typically discharged to various tributaries in the form of springs near the rivers at the foot of the slope. In this region, alpine meadows are the main vegetation type (Liu et al., 2012; Chen et al., 2014a; Liu et al., 2014).

Seasonally frozen soil is mainly distributed in the areas below $3500 \mathrm{~m}$ a.s.1. The maximum freezing depth is approximately $3 \mathrm{~m}$; freezing to this depth occurs in January (Ma et al., 2017). Alluvial sediments in the piedmont plain constitute a porous aquifer containing sands and gravels (Ma et al., 2017; Chang et al., 2018). The thickness of this aquifer is $20-50 \mathrm{~m}$, and it can store water in summer and maintain baseflow in winter to regulate streamflows (Ma et al., 2021a). In this area, the surface water and groundwater are hydraulically well connected, and the groundwater in the aquifer is recharged by the infiltration of river water and the lateral runoff of groundwater from the adjacent mountainous areas. In addition, the groundwater in this region is discharged into lower-elevation rivers in valleys or through 145 springs near the drainage basin outlet (Ma et al., 2017; Chang et al., 2018). The groundwater mainly flows from south to north based on the terrain. There are mainly alpine grassland and herbaceous plants in the areas below $3200 \mathrm{~m}$ a.s.l. (Liu et al., 2012). The vegetation types in higher-elevation areas are alpine 
shrubs (Liu et al., 2014).

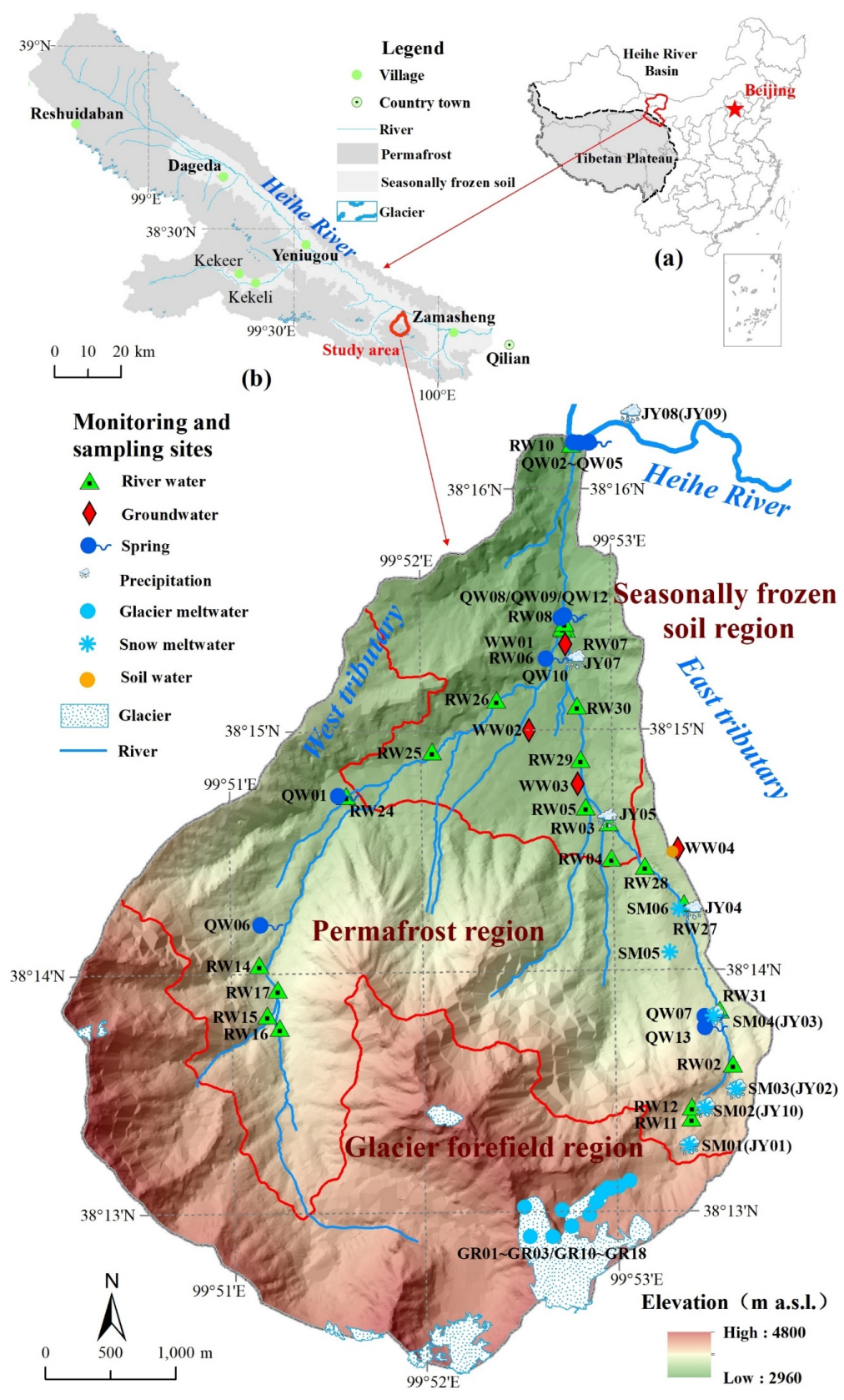

Figure 1. (a) Location of the Heihe River Basin in China; (b) the study area in the upper reaches of the Heihe River; and (c) a map showing the topography of the region and the monitoring and sampling sites. 


\section{The monitoring system}

\subsection{Layout of well groups}

There are four well groups in the study area, among which well groups WW01, WW02 and WW03 are located in areas with seasonally frozen soils and well group WW04 is located in a permafrost area (Fig. 1). The specific locations of these well groups are as follows: WW01 is located at the top of the mainstream in the northern part of the study area, near the intersection of the east and west tributaries; WW02 is located in the middle of the piedmont alluvial plain; WW03 is located at the top of the piedmont alluvial plain, near the bedrock in the southern mountainous area; and WW04 is located on the planation surface of a terrace in the eastern mountainous area. The details of these well groups are listed in Table 1, including their longitudinal and latitudinal coordinates, elevations, numbers of boreholes and their corresponding depths, and depths of the deployed pressure and temperature sensors. In each well group, all boreholes with depths of $3 \mathrm{~m}$ are filter tubes; these boreholes are used only to monitor soil temperatures. 165 At the bottom of each of the remaining boreholes is a $0.5-\mathrm{m}$ sand-settling pipe, and the upper part of each borehole is a $0.5-\mathrm{m}$ filter screen. The filter pipes are composed of high-density polyethylene, which is expected to have little effect on the measured groundwater properties. 
Table 1. The number, coordinates, elevation, depth and monitoring information of each well group at the corresponding depth, and the " $x$ " symbol indicates that no sensor was placed).

\begin{tabular}{|c|c|c|c|c|c|}
\hline \multirow{3}{*}{$\begin{array}{c}\text { Well group no. } \\
\text { Coordinates and elevation } \\
\text { Borehole no. }\end{array}$} & \multicolumn{5}{|c|}{ WW01 } \\
\hline & \multicolumn{5}{|c|}{$\mathrm{N}: 38^{\circ} 15^{\prime} 21.27^{\prime \prime}, \mathrm{E}: 99^{\circ} 52^{\prime} 45.38^{\prime \prime}, 3144 \mathrm{~m}$ a.s.1. } \\
\hline & WW01-01 & WW01-02 & WW01-03 & WW01-04 & WW01-05 \\
\hline Borehole depth (m) & 25 & 15 & 10 & 5 & 3 \\
\hline Pressure sensors & $\sqrt{ }$ & $\sqrt{ }$ & $\sqrt{ }$ & $\sqrt{ }$ & $\times$ \\
\hline \multicolumn{6}{|l|}{ Depth of temperature } \\
\hline & 23 & 15 & 10 & 5 & $0.2,0.5,1,1.5,2,3$ \\
\hline \multicolumn{6}{|l|}{ sensors $(\mathrm{m})$} \\
\hline Well group no. & \multicolumn{5}{|c|}{ WW02 } \\
\hline Coordinates and elevation & \multicolumn{5}{|c|}{ N: $99^{\circ} 52^{\prime} 33.68^{\prime \prime}, \mathrm{E}: 38^{\circ} 15^{\prime} 0.03^{\prime \prime}, 3250 \mathrm{~m}$ a.s.l. } \\
\hline Borehole no. & WW02-01 & WW02-02 & WW02-03 & WW02-04 & WW02-05 \\
\hline Borehole depth (m) & 30 & 15 & 10 & 5 & 3 \\
\hline Pressure sensors & $\times$ & $x$ & $x$ & $x$ & $x$ \\
\hline \multicolumn{6}{|l|}{ Depth of temperature } \\
\hline & 30 & 15 & 10 & 5 & $0.2,0.5,1,1.5,2,3$ \\
\hline \multicolumn{6}{|l|}{ sensors $(\mathrm{m})$} \\
\hline Well group no. & \multicolumn{5}{|c|}{ WW03 } \\
\hline Coordinates and elevation & \multicolumn{5}{|c|}{ N: $38^{\circ} 14^{\prime} 46.57^{\prime \prime}, \mathrm{E}: 99^{\circ} 52^{\prime} 48.87^{\prime \prime}, 3297$ m a.s.1. } \\
\hline Borehole no. & WW03-01 & WW03-02 & WW03-03 & WW03-04 & WW03-05 \\
\hline Borehole depth (m) & 30 & 20 & 10 & 5 & 3 \\
\hline Pressure sensors & $\sqrt{ }$ & $\sqrt{ }$ & $\times$ & $\times$ & $\times$ \\
\hline \multicolumn{6}{|l|}{ Depth of temperature } \\
\hline & 29 & 18.5 & 10 & 5 & $0.2,0.5,1,1.5,2,3$ \\
\hline sensors $(\mathrm{m})$ & & & & & \\
\hline
\end{tabular}


Table 1 (continued)

\begin{tabular}{|c|c|c|c|c|c|}
\hline Well group no. & \multicolumn{5}{|c|}{ WW04 } \\
\hline Coordinates and elevation & \multicolumn{5}{|c|}{$\mathrm{N}: 38^{\circ} 14^{\prime} 30.25^{\prime \prime}, \mathrm{E}: 99^{\circ} 53^{\prime} 20.21^{\prime \prime}, 3501 \mathrm{~m}$ a.s.1. } \\
\hline Borehole no. & WW04-01 & WW04-02 & WW04-03 & WW04-04 & WW04-05 \\
\hline Borehole depth (m) & 24.3 & 17.5 & 12 & 7 & 5 \\
\hline Pressure sensors & $\sqrt{ }$ & $x$ & $x$ & $x$ & $x$ \\
\hline \multicolumn{6}{|l|}{ Depth of temperature } \\
\hline sensors (m) & 23.6 & 17.2 & 11.8 & 6.7 & 4.7 \\
\hline
\end{tabular}

\subsection{Sediments and their mineral compositions in the well groups}

During drilling, lithological characterization was conducted at different depths, and the results are shown in Figure 2. In the seasonally frozen area of the piedmont alluvial plain, the sediments are mainly composed of mud-bearing pebble gravels that are very loose and poorly sorted (Ma et al., 2017; Chang et al., 2018). The drilling depths of the WW01 and WW02 well groups did not reach bedrock, while the drilling depth of well group WW03 reached weathered sandstone bedrock, indicating that the thickness of the aquifer located at the top of the piedmont alluvial plain is thinner than that in the middle and lower locations (Fig. 2). In addition, a clay layer with a thickness of approximately 3-6 m was found in the WW01, WW02 and WW03 well groups; this layer may be continuously distributed throughout the piedmont alluvial plain (Fig. 2).

The results obtained from well group WW04, which is located on the planation surface of the permafrost region, show that the perennially frozen layer is distributed at depths between 2 and $20 \mathrm{~m}$ underground (Fig. 2) and mainly consists of sand, gravel and ice. The active layer is $\sim 2 \mathrm{~m}$ thick and is composed of clay (Fig. 2). Depths below 20-24.3 m are characterized by the unfrozen subpermafrost aquifer, which is mainly composed of sand and gravel (Fig. 2). The intrapermafrost aquifer, which is located at an underground depth of $12 \mathrm{~m}$, is unfrozen within the permafrost layer and consists of a clay 
layer with a thickness of approximately $0.2 \mathrm{~m}$, as determined in the WW04 well group (Fig. 2).

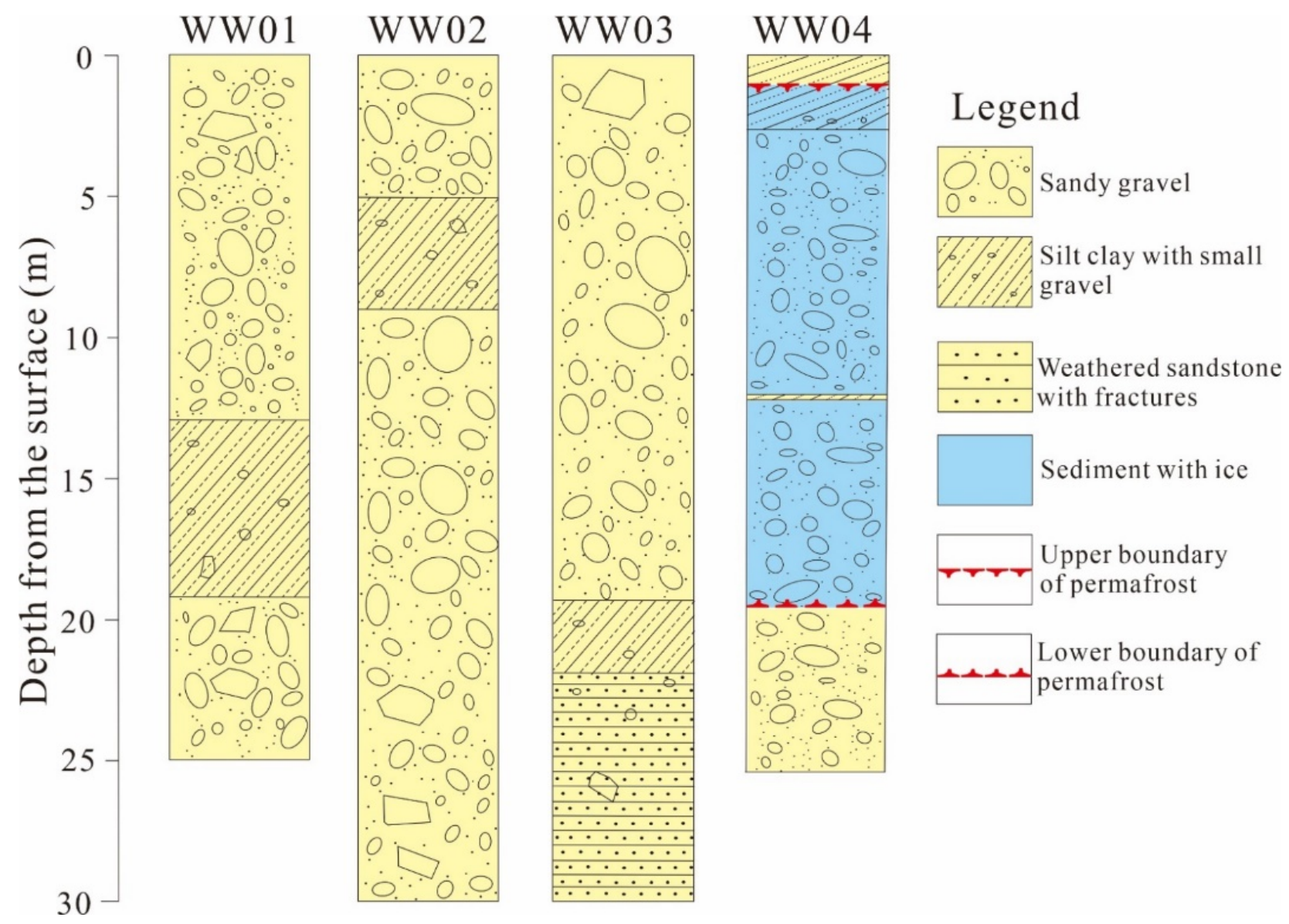

Figure 2. Lithologic diagram of the drilling cores of the well groups (Ma et al., 2017).

During the drilling of well groups WW03 and WW04, core samples were collected at 5-m intervals or at depths at which the core lithology changed. The length of each core sample was approximately 10 $\mathrm{cm}$. The core samples were sealed and placed in shading bags and then stored at $-20^{\circ} \mathrm{C}$. Then, the mineral composition and content of each sample were analyzed by X-ray diffraction (X'Pert PRO) in the State Key Laboratory of Geological Processes and Mineral Resources at the China University of Geosciences.

The results of the mineral composition and proportion analyses of the core samples are listed in Table 2. Chlorite, illite, quartz and K-feldspar are the main minerals present in these samples, accounting for more than $80 \%$ of all minerals. Calcite and dolomite account for $0 \%$ to $10 \%$ and $2 \%$ to $25 \%$ of the total 
mineral contents, respectively, while the proportions of amphibole do not exceed $8 \%$.

Table 2. Mineral compositions and proportions of the drilling core samples.

\begin{tabular}{|c|c|c|c|c|c|c|c|c|}
\hline \multirow{2}{*}{ Borehole no. } & \multirow{2}{*}{ Sample depth (m) } & \multicolumn{7}{|c|}{ Percentage of mineral composition (\%) } \\
\hline & & Chlorite & Illite & Quartz & K-feldspar & Calcite & Dolomite & Amphibole \\
\hline \multirow{8}{*}{ WW03-01 } & $0-0.2$ & 25 & 20 & 30 & 7 & 10 & 8 & 0 \\
\hline & $2.6-2.8$ & 25 & 15 & 30 & 10 & 10 & 10 & 0 \\
\hline & $7.5-7.7$ & 25 & 15 & 25 & 5 & 25 & 5 & 0 \\
\hline & $12.6-12.8$ & 25 & 15 & 33 & 10 & 10 & 5 & 2 \\
\hline & $17.4-17.6$ & 25 & 15 & 30 & 18 & 10 & 2 & 0 \\
\hline & $21.8-22.0$ & 25 & 15 & 40 & 18 & 2 & 0 & 0 \\
\hline & $24.6-24.8$ & 25 & 15 & 37 & 10 & 8 & 5 & 0 \\
\hline & $29.6-29.8$ & 25 & 15 & 40 & 5 & 15 & l & I \\
\hline \multirow{8}{*}{ WW04-01 } & $0.2-0.4$ & 25 & 15 & 45 & 12 & 3 & 0 & 0 \\
\hline & $1.6-2.0$ & 25 & 15 & 43 & 15 & 0 & 0 & 2 \\
\hline & $2.0-2.3$ & 25 & 15 & 45 & 15 & 0 & 0 & 0 \\
\hline & $5.0-5.2$ & 25 & 15 & 29 & 15 & 8 & 8 & 0 \\
\hline & $10.4-10.6$ & 15 & 25 & 30 & 15 & 5 & 10 & 0 \\
\hline & $15.6-15.8$ & 25 & 15 & 25 & 15 & 8 & 10 & 2 \\
\hline & $21.1-21.3$ & 25 & 15 & 25 & 22 & 5 & 0 & 8 \\
\hline & $24.2-24.4$ & 25 & 15 & 28 & 15 & 10 & 5 & 2 \\
\hline
\end{tabular}

\subsection{Monitoring of groundwater levels and ground temperatures}

During the installation of the monitoring systems, pressure sensors (HOBO U20-001-02, ONSET, USA) were placed at the bottoms of boreholes with depths of $25 \mathrm{~m}, 15 \mathrm{~m}$, and $10 \mathrm{~m}$ in well group WW01, depths of $30 \mathrm{~m}$ and $20 \mathrm{~m}$ in well group WW03, and depths of $24.3 \mathrm{~m}$ and $1.5 \mathrm{~m}$ in well group WW04 to 
monitor the groundwater levels at 30-minute intervals. No groundwater was observed in the other boreholes. The maximum water level depth at which the pressure sensors can obtain measurements is 30 $\mathrm{m}$, the measurement accuracy of these sensors is $\pm 1.5 \mathrm{~cm}$, and the resolution is $0.21 \mathrm{~cm}$. At the same time, temperature sensors (HOBO S-TMB-M0017, ONSET, USA) were also installed at different depths to monitor the ground temperatures, and the details of these sensors are summarized in Table 1. These temperature sensors can measure temperatures ranging from $-40{ }^{\circ} \mathrm{C}$ to $100{ }^{\circ} \mathrm{C}$. In the temperature range of $0-50{ }^{\circ} \mathrm{C}$, the measurement accuracy is $\pm 0.2{ }^{\circ} \mathrm{C}$, and the resolution is $0.03{ }^{\circ} \mathrm{C}$. The groundwater level and ground temperature monitoring began in September 2014 and lasted until September 2020.

The dynamic changes measured in the groundwater table in each borehole from July 2014 to September 2020 are shown in Figure 3. The groundwater tables of WW03 fluctuated greatly from June to September and that of WW01 were relatively stable. The groundwater tables of both WW03 and WW01 in November to May were much lower than those from June to September within each year. The groundwater table of the $1.5-\mathrm{m}$ deep borehole in the WW04 well group, which was located in the permafrost region, was basically close to the surface, especially from June to October, and decreased rapidly at the end of October and into November, while that in the 24.3-m deep borehole of the WW04 well group varied between 20.3 and $23.4 \mathrm{~m}$. 

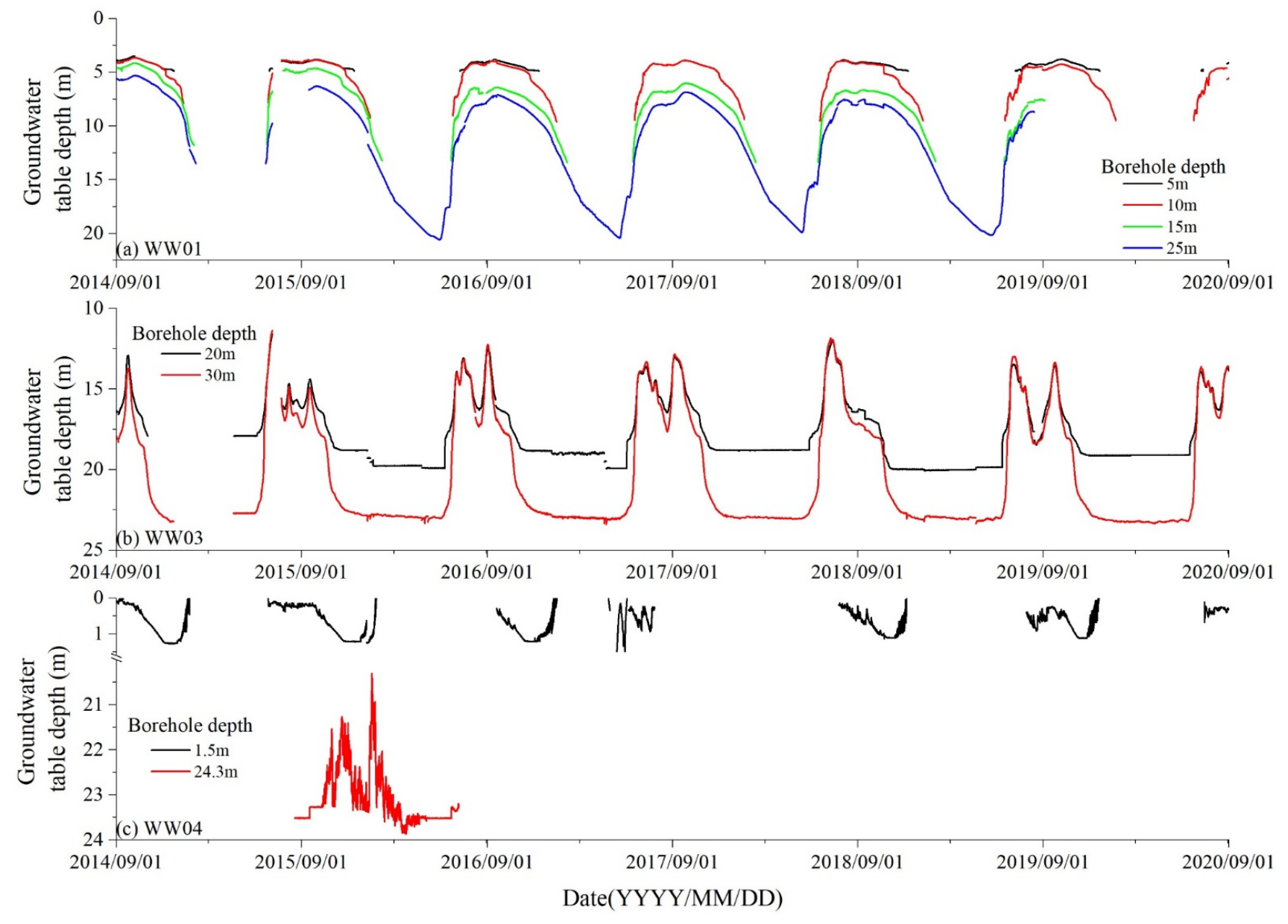

Figure 3. Variations in the groundwater table depths measured in boreholes.

Figure 4 shows the measured changes in ground temperatures. The ground temperatures fluctuated greatly at near-surface depths. According to the ground temperatures measured at different depths in the WW01, WW02 and WW03 well groups, the maximum freezing depths of seasonally frozen soil ranged from 3 to $5 \mathrm{~m}$, and the ground temperature fluctuation range was very small at depths greater than $10 \mathrm{~m}$ throughout the year. However, the ground temperature measured in the WW04 well group, which was located in the permafrost region, fluctuated mainly at depths below $2 \mathrm{~m}$, while the ground temperatures at other depths basically remained near $0^{\circ} \mathrm{C}$. 

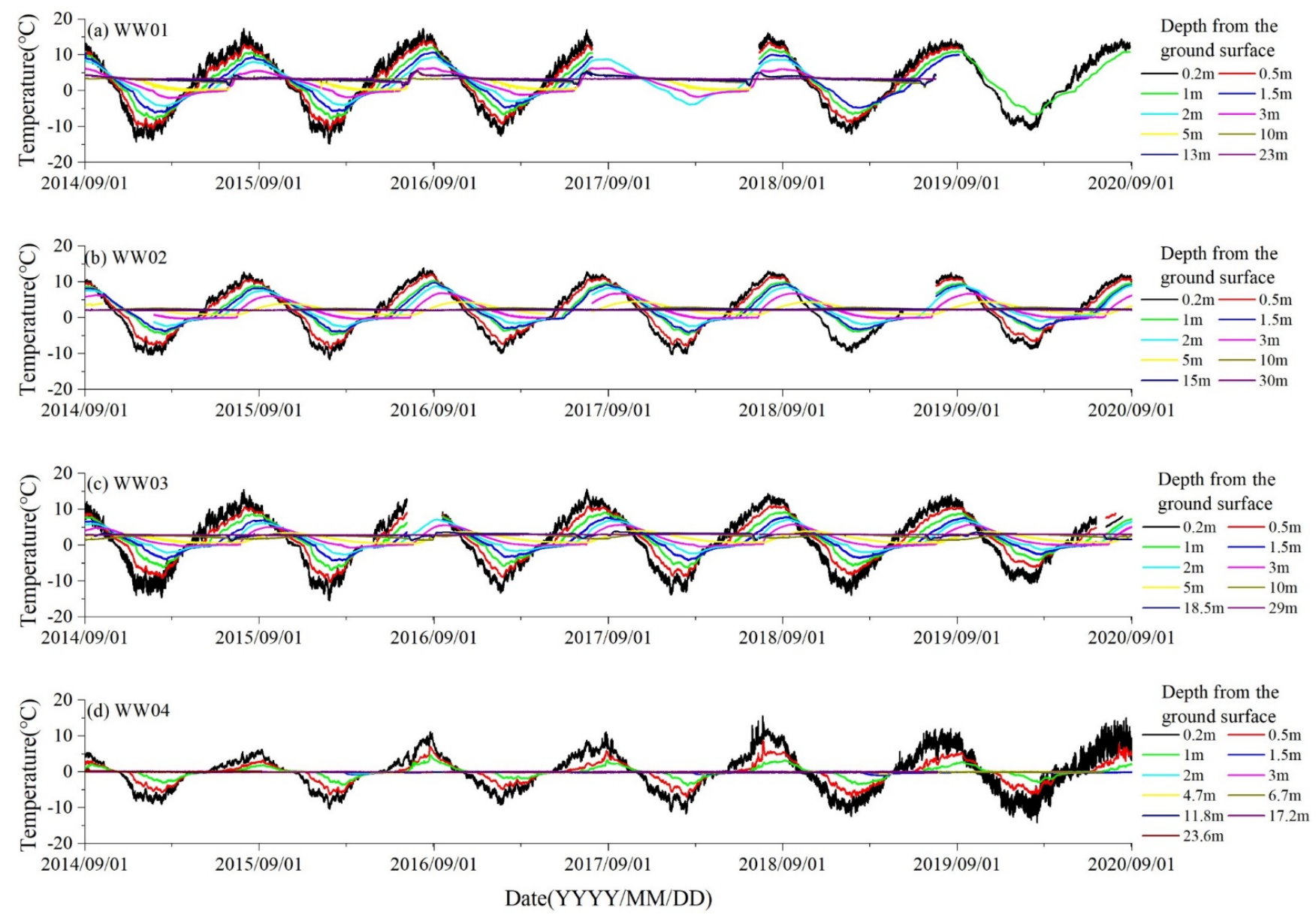

Figure 4. Variations in ground temperatures measured at different depths from the ground surface.

\section{Collection and analysis of water samples}

The following section is an introduction to the collection, preservation, and analysis of various water samples obtained in the study area over six years, from 2012 to 2017. Water samples were mainly collected in the following four stages: (1) frozen period (January), (2) thawing period (April and May), (3) thawed period (July and August) and (4) refreezing period (September). The locations of the sampling sites in the study area are shown in Figure 1. The methods used to obtain specific information regarding the different sampling sites and the analytical results of the samples are described in Section 5. 


\subsection{Sample collection and preservation}

In the study area, we collected seven types of water samples, including river water, precipitation, spring water, groundwater, soil water, glacier meltwater, and snow meltwater samples. The specific sampling site locations are shown in Figure 1. During the collection of all water samples (excluding the precipitation and soil water samples), the temperature (T), $\mathrm{pH}$, dissolved oxygen (DO), electrical conductivity (EC), and oxidoreduction potential (ORP) of the water samples were analyzed by a portable water quality analyzer (HQ40d, Hach, USA), which was calibrated for $\mathrm{pH}$ daily before use. Then, the sample bottles were cleaned three times with filtered water. When collecting groundwater samples, the water was pumped for 10 minutes to drain the old water from the wells and ensure the collection of representative water samples.

Six sets of water samples were collected for analyses of different chemical and isotopic indicators. (1) The water samples used for alkalinity titrations were stored in 50-mL polyethylene bottles. Three bottles of each sample were collected repeatedly without filtering, and alkalinity titrations were carried out within 24 hours after sampling. (2) The water samples collected for stable isotope ratio analyses were filtered with $0.22-\mu \mathrm{m}$-pore-diameter membranes and stored in 2-mL transparent glass bottles. (3) The water samples obtained for radioactive isotope analyses were collected and stored in 1000-mL highdensity polyethylene (HDPE) bottles. (4) The water samples collected to analyze water chemistry were filtered with $0.22-\mu \mathrm{m}$-pore-diameter membranes and stored in $50-\mathrm{mL}$ polyethylene bottles. Ultrapure $\mathrm{HNO}_{3}$ was added to the bottled samples used to analyze major cations and trace elements to ensure $\mathrm{pH}$ values $\leq 2$. (5) The water samples collected to analyze DOC were filtered with $0.45-\mu \mathrm{m}$ precombustion glass fiber filter membranes and stored in 40-mL brown threaded glass bottles. (6) The water samples obtained for analyses of DIC and of the $\delta^{13} \mathrm{C}$ values in DIC were filtered with $0.22-\mu \mathrm{m}$-pore-diameter membranes and stored in 40-mL brown threaded glass bottles. All the water samples described above were placed in sample bottles that were then sealed and stored at $4{ }^{\circ} \mathrm{C}$. In particular, there was no 
headspace left above the water samples when the sample bottles were sealed.

During the drilling process of well group WW04, soil samples were collected at different depths, and the samples were sealed and stored in boric acid in glass bottles at $-10{ }^{\circ} \mathrm{C}$. The specific borehole numbers and sample depths are listed in the corresponding dataset. Then, the soil samples were sent back to the laboratory to undergo vacuum extraction of water from the soils, and the stable isotope ratios were subsequently measured.

\subsection{Water chemistry}

The concentrations of major anions $\left(\mathrm{F}^{-}, \mathrm{Cl}^{-}, \mathrm{Br}^{-}, \mathrm{NO}_{3}^{-}, \mathrm{SO}_{4}^{2-}\right.$, and $\left.\mathrm{HPO}_{4}^{-}\right)$in the water samples were determined by ion chromatography. The water samples collected in 2012 and 2013 were analyzed at the State Key Laboratory of Biogeology and Environmental Geology at the China University of Geosciences using an ion chromatograph (IC 761/813, Metrohm, Switzerland). The remaining samples collected in 2014-2017 were analyzed by ion chromatography (Dionex ICS 1100, Thermo Elemental, USA) at the Laboratory of Basin Hydrology and Wetland Eco-restoration at the China University of Geosciences. The major cations $\left(\mathrm{Ca}^{2+}, \mathrm{K}^{+}, \mathrm{Mg}^{2+}\right.$, and $\left.\mathrm{Na}^{+}\right)$as well as $\mathrm{Si}, \mathrm{Sr}, \mathrm{Al}$ and $\mathrm{Fe}$, were measured at the Laboratory of Basin Hydrology and Wetland Eco-restoration at the China University of Geosciences by inductively coupled plasma atomic emission spectroscopy (IRIS INTRE II XSP, Thermo Elemental, USA). The analytical results of the different water samples are provided in the corresponding dataset.

\subsection{DOC and DIC}

The DOC concentrations in the water samples collected in 2012 and 2013 were measured by a total organic carbon analyzer (Multi N/C 2100 TOC, Analytik Jena AG, Germany) at the laboratory of the 285 Huazhong University of Science and Technology, and the analytical resolution was $0.001 \mathrm{ppb}$. The DIC concentrations in the water samples collected in 2012 and 2013 were analyzed by a stable isotope mass spectrometer (Delta V advantage, Thermo Elemental, USA) at the Third Institute of Oceanography, 
Ministry of Natural Resources. The DOC and DIC concentrations in the remaining water samples collected in 2014-2017 were analyzed by a total organic carbon analyzer (Aurora 1030W, OI, USA) at the Laboratory of Basin Hydrology and Wetland Eco-restoration, China University of Geosciences, and the precision was $50 \mathrm{ppb}$.

\subsection{Analysis of stable isotopes}

The ${ }^{13} \mathrm{C}$ concentrations in the DIC of the water samples collected in 2012 and 2013 were analyzed at the same time the DIC concentrations were measured using a stable isotope mass spectrometer (Delta V advantage, Thermo Elemental, USA) at the Third Institute of Oceanography, Ministry of Natural Resources. The ${ }^{13} \mathrm{C}$ concentrations in the DIC of the groundwater samples collected at different borehole depths (WW04-01, WW04-07, WW03-01, WW03-02, WW01-01, WW01-02, and WW01-03) and of the spring water samples (QW02, QW03, QW04, QW05 and QW08) collected in 2014 were measured using wavelength-scanned cavity ring-down spectroscopy (G2131-I, Picarro, USA). The ${ }^{13} \mathrm{C}$ in DIC results was expressed by the relative abundance $(\delta)$ of ${ }^{13} \mathrm{C}$ in parts per thousand (\%o), which was compared with Vienna PeeDee Belemnite (V-PDB). The analysis results of the water samples obtained in 2012 and 2013 are given in the corresponding dataset, and the results obtained for the samples obtained in 2014 can be seen in Table 3 .

The ${ }^{2} \mathrm{H}$ and ${ }^{18} \mathrm{O}$ isotopic compositions in the water samples collected in 2012 and 2013 were measured with a stable isotope ratio mass spectrometer (Finnigan MAT253, Thermo Elemental, USA) at the State Key Laboratory of Biogeology and Environmental Geology at the China University of Geosciences; the corresponding values measured in the water samples collected in other periods were determined by an ultrahigh-precision liquid water isotope analyzer (L2130-I, Picarro, USA) at the School of Environmental Studies at the China University of Geosciences. Each water sample was analyzed with 7 repetitions, and the results from the first three repetitions were ignored to eliminate the influence of the previous sample. At the same time, we established an internal calibration equation using standard samples 
(Vienna Standard Mean Ocean Water) to calibrate the analytical results. The results were expressed as relative abundance values $(\delta)$ in parts per thousand (\%o) compared with the standard samples. The analytical precision levels of ${ }^{2} \mathrm{H}$ and ${ }^{18} \mathrm{O}$ achieved with the first utilized methods were $1.5 \%$ and $0.2 \%$, and those obtained with the second utilized method were $0.5 \%$ and $0.1 \%$, respectively. The measurement results are given in the corresponding dataset.

\subsection{Analysis of ${ }^{3} \mathrm{H}$ and ${ }^{14} \mathrm{C}$ isotopes}

The ${ }^{3} \mathrm{H}$ and ${ }^{14} \mathrm{C}$ concentrations in the groundwater samples obtained at different borehole depths (WW04-01, WW04-07, WW03-01, WW03-02, WW01-01, WW01-02, and WW01-03) and the spring water samples (QW02, QW03, QW04, QW05 and QW08) collected in 2014 were analyzed to investigate the groundwater age. The water samples collected for ${ }^{3} \mathrm{H}$ analysis were concentrated by electrolysis and analyzed by the liquid scintillation method (QuantulusTm 1220, PerkinElmer, USA) at the Institute of Karst Geology of the China Geological Survey. The ${ }^{3} \mathrm{H}$ concentrations in the water samples were expressed in tritium units (TU), and the detection limit was $\pm 1 \mathrm{TU}$. The ${ }^{14} \mathrm{C}$ concentrations in the water samples were determined by an accelerated mass spectrometer (3MV Tandetron AMS, HVEE, Netherlands) at the Xi' an AMS Center in China. Under vacuum conditions, the carbonates in the samples were removed by filtration with glass filter paper, followed by the addition of $85 \%$ phosphoric acid to the samples. The standard samples used for ${ }^{14} \mathrm{C}$ analysis were prepared according to the method described by Liu et al. (Liu et al., 2019). The ${ }^{14} \mathrm{C}$ analysis results were expressed as percent modern carbon (pmC), and the analysis precision was $2 \%$. The results of this analysis are listed in Table 3. 
Table 3. Results of radioisotope analysis of the water samples (Ma et al., 2017).

\begin{tabular}{|c|c|c|c|c|c|}
\hline \multirow{2}{*}{ Sample No. } & \multicolumn{2}{|c|}{$\delta^{13} \mathrm{C}(\%)$} & \multirow{2}{*}{${ }^{3} \mathrm{H}(\mathrm{TU})$} & \multicolumn{2}{|c|}{${ }^{14} \mathrm{C}$ activity (pmC) } \\
\hline & $\delta^{13} \mathrm{C}$ & Error $(1 \sigma)$ & & ${ }^{14} \mathrm{C}$ activity & Error $(1 \sigma)$ \\
\hline $\begin{array}{l}\text { WW04-01 (24.3-m borehole } \\
\text { depth) }\end{array}$ & -16.77 & 0.51 & n.d. & 76.43 & 0.32 \\
\hline $\begin{array}{c}\text { WW04-07 (1.5-m borehole } \\
\text { depth) }\end{array}$ & -13.60 & 0.57 & 15.11 & 96.34 & 0.31 \\
\hline WW03-01 (30-m borehole depth) & -8.79 & 0.57 & 19.38 & 51.77 & 0.22 \\
\hline WW03-02 (20-m borehole depth) & n.d. & n.d. & 16.22 & n.d. & n.d. \\
\hline WW01-01 (25-m borehole depth) & -5.92 & 0.53 & 16.95 & 49.60 & 0.18 \\
\hline WW01-02 (15-m borehole depth) & n.d. & n.d. & 24.18 & 44.38 & n.d. \\
\hline WW01-03 (10-m borehole depth) & n.d. & n.d. & 16.20 & n.d. & n.d. \\
\hline QW02 (spring) & n.d. & n.d. & 27.83 & n.d. & n.d. \\
\hline QW03 (spring) & n.d. & n.d. & 13.84 & n.d. & n.d. \\
\hline QW04 (spring) & n.d. & n.d. & 13.61 & 43.05 & 0.19 \\
\hline QW05 (spring) & -5.09 & 0.7 & 43.59 & n.d. & n.d. \\
\hline QW08 (spring) & n.d. & n.d. & 18.58 & n.d. & n.d. \\
\hline
\end{tabular}

"n.d." means not determined.

\section{Data availability}

All data mentioned in this paper can be obtained at https://doi.org/10.5281/zenodo.5184470 (Ma et al., 2021b). The original data were divided into two files. The first file contains monitoring data, including groundwater levels and ground temperatures. The second file includes the results of the sample analyses and the numbers and locations (longitudinal and latitudinal coordinates) of the sampling sites.

\section{Conclusions}

This study presents a systematic monitoring site scheme located in an alpine catchment in the headwater region of the Heihe River with distributed permafrost and seasonally frozen ground. Four sets of clustered wells were drilled, and the groundwater levels and ground temperatures were continuously monitored for six years at 30-minute intervals. We collected samples of sediments, river water, 
precipitation, spring water, groundwater from boreholes, soil water, glacier meltwater, and snow meltwater from 2012 to 2017 during the frozen period (January), thawing period (April and May), thawed period (July and August) and refreezing period (September). The major anions $\left(\mathrm{F}^{-}, \mathrm{Cl}^{-}, \mathrm{Br}^{-}, \mathrm{NO}_{3}{ }^{-}, \mathrm{SO}_{4}{ }^{2-}\right.$, and $\left.\mathrm{HPO}_{4}^{-}\right)$; the major cations $\left(\mathrm{Ca}^{2+}, \mathrm{K}^{+}, \mathrm{Mg}^{2+}\right.$, and $\left.\mathrm{Na}^{+}\right)$; the $\mathrm{Si}, \mathrm{Sr}, \mathrm{Al}$, and $\mathrm{Fe}$ concentrations; the DOC and DIC concentrations; and isotopic compositions (including the stable isotopes ${ }^{13} \mathrm{C}$ in DIC and ${ }^{2} \mathrm{H}$ and ${ }^{18} \mathrm{O}$ in water and the radioisotopes ${ }^{3} \mathrm{H}$ and ${ }^{14} \mathrm{C}$ ) were measured in the water samples.

This study is among the few attempts to obtain groundwater level, temperature, water chemistry and isotopic data representing groundwater exiting the ground from springs and directly sampled from drilled boreholes; thus, these data in combination with other measurements, such as river discharge, precipitation, water chemistry and isotopic value measurements of glacier and snow meltwater can be used to investigate groundwater flow systems and groundwater and surface interactions in areas with distributed permafrost and seasonally frozen ground. The data obtained in this study can be used to explore the different kinds of groundwater flow-related issues, including but not limited to (1) the effect of the freezethaw process of soils on groundwater flow and the interactions between groundwater and surface water; (2) the interplay between permafrost degradation and groundwater flow changes; and (3) the water quality in alpine catchments under the impacts of seasonal freeze-thaw processes in soils and permafrost degradation. Based on the existing data, the following efforts should be made in the future to obtain a better understanding of the coupled hydrobiogeochemical cycles under the impacts of climate change in alpine catchments: (1) coupling with other monitoring systems (meteorological monitoring systems, remote sensing monitoring systems, and hydrological monitoring systems) to obtain data representing climatic characteristics, the permafrost distribution and its changes, ecological conditions, and river discharges and levels; (2) developing combined flow-heat-solute transport models to understand the impacts of seasonal freeze-thaw processes in soils and permafrost degradation on groundwater flow, on the interaction between groundwater and surface water, and on the water quality and element cycles; and (3) correctly evaluating the impacts of groundwater flow changes on the regional biogeochemical cycle 
under climate change.

Author contributions. RM and ZS designed the whole monitoring system. ZP, YH, QC, MG, SW, JB, XL, YP, and LZ carried out the field work in the Hulugou catchment. ZP and RM collated the dataset. All coauthors participated in the writing and revision of the paper.

Competing interests. The authors declare that they have no conflicts of interest.

Acknowledgments. We sincerely thank the team working in the Qilian Alpine Ecology and Hydrology Research Station, Northwest Institute of Eco-Environment and Resources, Chinese Academy of Sciences.

Financial support. This work was financially supported by the Strategic Priority Research Program of the Chinese Academy of Sciences (No. XDA20100103), the National Natural Science Foundation of China (No. 41772270), and the Natural Sciences Foundation of Hubei Province of China (No. 2019CFA013).

\section{References}

Alekseyev, V. R.: Cryogenesis and geodynamics of icing valleys, Geodynamics \& Tectonphsics, 6, 171224, https://doi.org/10.5800/GT-2015-6-2-0177, 2015.

Amanambu, A. C., Obarein, O. A., Mossa, J., Li, L., Ayeni, S. S., Balogun, O., Oyebamiji, A., and Ochege, F. U.: Groundwater system and climate change: Present status and future considerations, J. Hydrol., 589, 125163, https://doi.org/10.1016/j.jhydrol.2020.125163, 2020.

Behnke, M. I., McClelland, J. W., Tank, S. E., Kellerman, A. M., Holmes, R. M., Haghipour, N., Eglinton, T. I., Raymond, P. A., Suslova, A., Zhulidov, A. V., Gurtovaya, T., Zimov, N., Zimov, S., Mutter, E. A., Amos, E., and Spencer, R. G. M.: Pan-Arctic riverine dissolved organic matter: Synchronous molecular stability, shifting sources and subsidies, Glob. Biogeochem. Cycle, 35, e2020GB006871, https://doi.org/10.1029/2020GB006871, 2021.

Bian, Q., Xu, Z., Zheng, H., Li, K., Liang, J., Fei, W., Shi, C., Zhang, S., and Yang, Z.: Multiscale changes 
in snow over the Tibetan Plateau during 1980-2018 represented by reanalysis data sets and satellite observations, J. Geophys. Res.-Atmos., 125, e2019JD031914, https://doi.org/10.1029/2019JD031914, 2020.

Bibi, S., Wang, L., Li, X., Zhou, J., Chen, D., and Yao, T.: Climatic and associated cryospheric, biospheric, and hydrological changes on the Tibetan Plateau: a review, Int. J. Climatol., 38, e1-e17, https://doi.org/10.1002/joc.5411, 2018.

Carey, S. K., Boucher, J. L., and Duarte, C. M.: Inferring groundwater contributions and pathways to streamflow during snowmelt over multiple years in a discontinuous permafrost subarctic environment (Yukon, Canada), Hydrogeol. J., 21, 67-77, https://doi.org/10.1007/s10040-012-09209, 2013.

Chang, Q., Ma, R., Sun, Z., Zhou, A., Hu, Y., and Liu, Y.: Using isotopic and geochemical tracers to determine the contribution of glacier-snow meltwater to streamflow in a partly glacierized alpinegorge catchment in northeastern Qinghai-Tibet Plateau, J. Geophys. Res.-Atmos., 123, 1003710056, https://doi.org/10.1029/2018JD028683, 2018.

Chen, D., Xu, B., Yao, T., Guo, Z., Cui, P., Chen, F., Zhang, R., Zhang, X., Zhang, Y., Fan, J., Hou, Z., and Zhang, T.: Assessment of past, present and future environmental changes on the Tibetan Plateau, Chin. Sci. Bull., 60, 3025-3035, https://doi.org/10.1360/N972014-01370, 2015.

Chen, R., Yang, Y., Han, C., Liu, J., Kang, E., Song, Y., and Liu, Z.: Field experimental research on hydrological function over several typical underlying surfaces in the cold regions of western China, Advances in Earth Science, 29, 507-514, https://doi.org/10.11867/j.issn.1001-8166.2014.04.0507, 2014a.

Chen, R. S., Song, Y. X., Kang, E. S., Han, C. T., Liu, J. F., Yang, Y., Qing, W. W., and Liu, Z. W.: A cryosphere-hydrology observation system in a small alpine watershed in the Qilian Mountains of China and its meteorological gradient, Arct. Antarct. Alp. Res., 46, 505-523, https://doi.org/10.1657/1938-4246-46.2.505, 2014b.

Cheng, G. and Jin, H.: Permafrost and groundwater on the Qinghai-Tibet Plateau and in northeast China, Hydrogeol. J., 21, 5-23, https://doi.org/10.1007/s10040-012-0927-2, 2013.

Clark, I. D. and Lauriol, B.: Aufeis of the Firth River basin, northern Yukon, Canada: Insights into permafrost hydrogeology and karst, Arct. Alp. Res., 29, 240-252, https://doi.org/10.1080/00040851.1997.12003239, 1997.

Cochand, M., Molson, J., and Lemieux, J. M.: Groundwater hydrogeochemistry in permafrost regions, Permafrost Periglacial Process., 30, 90-103, https://doi.org/10.1002/ppp.1998, 2019.

Connolly, C. T., Cardenas, M. B., Burkart, G. A., Spencer, R. G. M., and McClelland, J. W.: Groundwater as a major source of dissolved organic matter to Arctic coastal waters, Nat. Commun., 11, 1-8, https://doi.org/10.1038/s41467-020-15250-8, 2020.

Cuo, L., Li, N., Liu, Z., Ding, J., Liang, L., Zhang, Y., and Gong, T.: Warming and human activities 
induced changes in the Yarlung Tsangpo basin of the Tibetan plateau and their influences on streamflow, J. Hydrol., 25, 100625, https://doi.org/10.1016/j.ejrh.2019.100625, 2019.

Evans, S. G., Ge, S., and Liang, S.: Analysis of groundwater flow in mountainous, headwater catchments with permafrost, Water Resour. Res., 51, 9564-9576, https://doi.org/10.1002/2015WR017732, 2015.

Evans, S. G., Yokeley, B., Stephens, C., and Brewer, B.: Potential mechanistic causes of increased baseflow across northern Eurasia catchments underlain by permafrost, Hydrol. Process., 34, 26762690, https://doi.org/10.1002/hyp.13759, 2020.

Frey, K. E. and McClelland, J. W.: Impacts of permafrost degradation on arctic river biogeochemistry, Hydrol. Process., 23, 169-182, https://doi.org/10.1002/hyp.7196, 2009.

Ge, S., McKenzie, J., Voss, C., and Wu, Q.: Exchange of groundwater and surface-water mediated by permafrost response to seasonal and long term air temperature variation, Geophys. Res. Lett., 38, L14402, https://doi.org/10.1029/2011GL047911, 2011.

Green, T. R., Taniguchi, M., Kooi, H., Gurdak, J. J., Allen, D. M., Hiscock, K. M., Treidel, H., and Aureli, A.: Beneath the surface of global change: Impacts of climate change on groundwater, J. Hydrol., 405, 532-560, https://doi.org/10.1016/j.jhydrol.2011.05.002, 2011.

Gui, J., Li, Z., Yuan, R., and Xue, J.: Hydrograph separation and the influence from climate warming on runoff in the north-eastern Tibetan Plateau, Quat. Int., 525, 45-53, https://doi.org/10.1016/j.quaint.2019.09.002, 2019.

Harlan, R. L.: Analysis of coupled heat-fluid transport in partially frozen soil, Water Resour. Res., 9, 1314-1323, https://doi.org/10.1029/WR009i005p01314, 1973.

Hartmann, D. L., Tank, A., and Rusticucci, M.: The IPCC Fifth Assessment Report (AR5), Climate Change 2013: The Physical Science Basis, IPCC, Stockholm, 2013.

Hu, Y., Ma, R., Wang, Y., Chang, Q., Wang, S., Ge, M., Bu, J., and Sun, Z.: Using hydrogeochemical data to trace groundwater flow paths in a cold alpine catchment, Hydrol. Process., 33, 1942-1960, https://doi.org/10.1002/hyp.13440, 2019.

Huang, X., Deng, J., Wang, W., Feng, Q., and Liang, T.: Impact of climate and elevation on snow cover using integrated remote sensing snow products in Tibetan Plateau, Remote Sens. Environ., 190, 274-288, https://doi.org/10.1016/j.rse.2016.12.028, 2017.

Huryn, A. D., Gooseff, M. N., Hendrickson, P. J., Briggs, M. A., Tape, K. D., and Terry, N. C.: Aufeis fields as novel groundwater-dependent ecosystems in the arctic cryosphere, Limnol. Oceanogr., 66, 607-624, https://doi.org/10.1002/1no.11626, 2020.

Immerzeel, W. W., Van Beek, L. P. H., and Bierkens, M. F. P.: Climate change will affect the Asian water towers, Science, 328, 1382-1385, https://doi.org/10.1126/science.1183188, 2010.

470 Jin, H., Luo, D., Wang, S., Lü, L., and Wu, J.: Spatiotemporal variability of permafrost degradation on the Qinghai-Tibet Plateau, Sci. Cold Arid Reg., 3, 281-305, https://doi.org/10.3724/SP.J.1226.2011.00281, 2011.

Kuang, X. and Jiao, J. J.: Review on climate change on the Tibetan Plateau during the last half century, J. 
Geophys. Res.-Atmos., 121, 3979-4007, https://doi.org/10.1002/2015JD024728, 2016.

Li, D., Cui, B., Wang, Y., Wang, Y., and Jiang, B.: Source and quality of groundwater surrounding the Qinghai Lake, NE Qinghai-Tibet Plateau, Groundwater, 59, 245-255, https://doi.org/10.1111/gwat.13042, 2020a.

Li, X., Long, D., Huang, Q., Han, P., Zhao, F., and Wada, Y.: High-temporal-resolution water level and storage change data sets for lakes on the Tibetan Plateau during 2000-2017 using multiple altimetric missions and Landsat-derived lake shoreline positions, Earth Syst. Sci. Data, 11, 1603-1627, https://doi.org/10.5194/essd-11-1603-2019, 2019.

Li, X., Ding, Y., Han, T., Sillanpää, M., Jing, Z., You, X., Liu, S., Yang, C., Yu, C., and Li, G.: Seasonal and interannual changes of river chemistry in the source region of Yellow River, Tibetan Plateau, Appl. Geochem., 119, 104638, https://doi.org/10.1016/j.apgeochem.2020.104638, 2020b.

Liu, S., Yang, Y., Sheng, X., Zhang, H., Jiang, Y. X., and Shi, H.: ${ }^{14}$ C Sample preparation vacuum line and graphite preparation method for ${ }^{14} \mathrm{C}$-AMS measurement, Rock and Mineral Analysis, 38, 270 279, https://doi.org/10.15898/j.cnki.11-2131/td.201807120084, 2019.

Liu, S., Yao, X., Guo, W., Xu, J., Shangguan, D., Wei, J., Bao, W., and Wu, L.: The contemporary glaciers in China based on the Second Chinese Glacier Inventory, Acta Geographica Sinica, 70, 3-16, https://doi.org/10.11821/d1xb201501001, 2015.

Liu, Z., Chen, R., Song, Y., and Han, C.: Characteristics of rainfall interception for four typical shrubs in Qilian Mountain, Acta Ecologica Sinica, 32, 1337-1346, https://doi.org/10.5846/stxb201012211822, 2012.

Liu, Z., Chen, R., Song, Y., and Han, C.: Water holding capacity of mosses under alpine shrubs in Qilian Mountains, Arid Land Geography, 37, https://doi.org/10.13826/j.cnki.cn65-1103/x.2014.04.007, 2014.

Liu, Z., Yao, Z., Wang, R., and Yu, G.: Estimation of the Qinghai-Tibetan Plateau runoff and its contribution to large Asian rivers, Sci. Total Environ., 749, 141570, https://doi.org/10.1016/j.scitotenv.2020.141570, 2020.

Lu, H., Wang, X., Ma, H., Tan, H., Vandenberghe, J., Miao, X., Li, Z., Sun, Y., An, Z., and Cao, G.: The Plateau Monsoon variation during the past $130 \mathrm{kyr}$ revealed by loess deposit at northeast QinghaiTibet (China), Glob. Planet. Change, 41, 207-214, https://doi.org/10.1016/j.gloplacha.2004.01.006, 2004.

Ma, J., Ding, Z., Edmunds, W. M., Gates, J. B., and Huang, T.: Limits to recharge of groundwater from Tibetan plateau to the Gobi desert, implications for water management in the mountain front, J. Hydrol., 364, 128-141, https://doi.org/10.1016/j.jhydrol.2008.10.010, 2009.

Ma, R., Sun, Z., Chang, Q., Ge, M., and Pan, Z.: Control of the Interactions between Stream and Groundwater by Permafrost and Seasonal Frost in an Alpine Catchment, Northeastern Tibet Plateau, China, J. Geophys. Res.-Atmos., 126, e2020JD033689, https://doi.org/10.1029/2020JD033689, 2021a. 
Ma, R., Sun, Z., Pan, Z., Hu, Y., and Chang, Q.: Datasets for research on groundwater flow and its interactions with surface water in an alpine catchment on the northeast Tibetan Plateau, China (1.0) [dataset], https://doi.org/10.5281/zenodo.5184470, $2021 \mathrm{~b}$.

Ma, R., Sun, Z., Hu, Y., Chang, Q., Wang, S., Xing, W., and Ge, M.: Hydrological connectivity from glaciers to rivers in the Qinghai-Tibet Plateau: roles of suprapermafrost and subpermafrost groundwater, Hydrol. Earth Syst. Sci., 21, 4803-4823, https://doi.org/10.5194/hess-21-4803-2017, 2017.

McClymont, A. F., Hayashi, M., Bentley, L. R., Muir, D., and Ernst, E.: Groundwater flow and storage within an alpine meadow-talus complex, Hydrol. Earth Syst. Sci., 14, 859-872, https://doi.org/10.5194/hess-14-859-2010, 2010.

McKenzie, J. M. and Voss, C. I.: Permafrost thaw in a nested groundwater-flow system, Hydrogeol. J., 21, 299-316, https://doi.org/10.1007/s10040-012-0942-3, 2013.

O'Donnell, J. A., Aiken, G. R., Walvoord, M. A., and Butler, K. D.: Dissolved organic matter composition of winter flow in the Yukon River basin: Implications of permafrost thaw and increased groundwater discharge, Glob. Biogeochem. Cycle, 26, GB0E06, https://doi.org/10.1029/2012GB004341, 2012.

Pritchard, H. D.: Asia's shrinking glaciers protect large populations from drought stress, Nature, 569, 649654, https://doi.org/10.1038/s41586-019-1240-1, 2019.

Prowse, T. D. and Brown, K.: Hydro-ecological effects of changing Arctic river and lake ice covers: a review, Hydrol. Res., 41, 454-461, https://doi.org/10.2166/nh.2010.142, 2010.

Pu, T., Qin, D., Kang, S., Niu, H., He, Y., and Wang, S.: Water isotopes and hydrograph separation in different glacial catchments in the southeast margin of the Tibetan Plateau, Hydrol. Process., 31, 3810-3826, https://doi.org/10.1002/hyp.11293, 2017.

Pu, T., Kong, Y., Kang, S., Shi, X., Zhang, G., Wang, S., Cao, B., Wang, K., Hua, H., and Chen, P.: New insights into trace elements in the water cycle of a karst-dominated glacierized region, southeast Tibetan Plateau, Sci. Total Environ., 751, 141725, https://doi.org/10.1016/j.scitotenv.2020.141725, 2021.

Qiu, J.: China: The third pole, Nature, 454, 393-396, https://doi.org/10.1038/454393a, 2008.

Ran, Y., Li, X., and Cheng, G.: Climate warming over the past half century has led to thermal degradation of permafrost on the Qinghai-Tibet Plateau, Cryosphere, 12, 595-608, https://doi.org/10.5194/tc12-595-2018, 2018.

Schaefer, K., Zhang, T., Bruhwiler, L., and Barrett, A. P.: Amount and timing of permafrost carbon release in response to climate warming, Tellus Ser. B-Chem. Phys. Meteorol., 63, 168-180, https://doi.org/10.1111/j.1600-0889.2010.00527.x, 2011.

Schohl, G. A. and Ettema, R.: Two-dimensional spreading and thickening of aufeis, J. Glaciol., 36, 169178, https://doi.org/10.3189/S0022143000009412, 1990.

Sharma, L., Greskowiak, J., Ray, C., Eckert, P., and Prommer, H.: Elucidating temperature effects on seasonal variations of biogeochemical turnover rates during riverbank filtration, J. Hydrol., 428- 
429, 104-115, https://doi.org/10.1016/j.jhydrol.2012.01.028, 2012.

Shen, S., Song, C., Cheng, C., and Ye, S.: The coupling impact of climate change on streamflow complexity in the headwater area of the northeastern Tibetan Plateau across multiple timescales, $\mathrm{J}$. Hydrol., 588, 124996, https://doi.org/10.1016/j.jhydrol.2020.124996, 2020.

Solomon, S., Qin, D., Manning, M., Chen, Z., Marquis, M., Averyt, K. B., Tignor, M., and Miller, H. L.: Climate Change 2007: The Physical Science Basis. Contribution of Working Group I to the Fourth Assessment Report of the Intergovernmental Panel on Climate Change, IPCC, Cambridge, United Kingdom and New York, NY, USA, 996 pp, 2007.

Tan, H., Chen, X., Shi, D., Rao, W., Liu, J., Liu, J., Eastoe, C. J., and Wang, J.: Base flow in the Yarlungzangbo River, Tibet, maintained by the isotopically-depleted precipitation and groundwater discharge, Sci. Total Environ., 759, 143510, https://doi.org/10.1016/j.scitotenv.2020.143510, 2021.

Terry, N., Grunewald, E., Briggs, M., Gooseff, M., Huryn, A. D., Kass, M. A., Tape, K. D., Hendrickson, P., and Lane Jr, J. W.: Seasonal subsurface thaw dynamics of an aufeis feature inferred from geophysical methods, J. Geophys. Res.-Earth Surf., 125, e2019JF005345, https://doi.org/10.1029/2019JF005345, 2020.

Walvoord, M. A., Voss, C. I., and Wellman, T. P.: Influence of permafrost distribution on groundwater flow in the context of climate-driven permafrost thaw: Example from Yukon Flats Basin, Alaska, United States, Water Resour. Res., 48, W07524, https://doi.org/10.1029/2011WR011595, 2012.

Wang, G., Liu, L. a., Liu, G., Hu, H., and Li, T.: Impacts of grassland vegetation cover on the active-layer thermal regime, northeast Qinghai-Tibet Plateau, China, Permafrost Periglacial Process., 21, 335344, https://doi.org/10.1002/ppp.699, 2010.

Wang, P., Huang, Q., Pozdniakov, S. P., Liu, S., Ma, N., Wang, T., Zhang, Y., Yu, J., Xie, J., Fu, G., Frolova, N. L., and Liu, C.: Potential role of permafrost thaw on increasing Siberian river discharge, Environ. Res. Lett., 16, 034046, https://doi.org/10.1088/1748-9326/abe326, 2021.

Wang, Y., Yang, H., Gao, B., Wang, T., Qin, Y., and Yang, D.: Frozen ground degradation may reduce future runoff in the headwaters of an inland river on the northeastern Tibetan Plateau, J. Hydrol., 564, 1153-1164, https://doi.org/10.1016/j.jhydrol.2018.07.078, 2018.

575 Wisser, D., Marchenko, S., Talbot, J., Treat, C., and Frolking, S.: Soil temperature response to 21 st century global warming: the role of and some implications for peat carbon in thawing permafrost soils in North America, Earth Syst. Dynam., 2, 121-138, https://doi.org/10.5194/esd-2-121-2011, 2011.

Woo, M.-k.: Permafrost Hydrology, Springer, Berlin, Germany, https://doi.org/10.1007/978-3-64223462-0, 2012.

$\mathrm{Xu}$, M., Kang, S., Wang, X., Pepin, N., and Wu, H.: Understanding changes in the water budget driven by climate change in cryospheric-dominated watershed of the northeast Tibetan Plateau, China, Hydrol. Process., 33, 1040-1058, https://doi.org/10.1002/hyp.13383, 2019.

Xu, X., Zhang, Z., and Wu, Q.: Simulation of permafrost changes on the Qinghai-Tibet Plateau, China, over the past three decades, Int. J. Digit. Earth, 10, 522-538, 
https://doi.org/10.1080/17538947.2016.1237571, 2017.

Yang, N. and Wang, G.: Moisture sources and climate evolution during the last $30 \mathrm{kyr}$ in northeastern Tibetan Plateau: Insights from groundwater isotopes $\left({ }^{2} \mathrm{H},{ }^{18} \mathrm{O},{ }^{3} \mathrm{H}\right.$ and $\left.{ }^{14} \mathrm{C}\right)$ and water vapour trajectories modeling, Quat. Sci. Rev., 242, https://doi.org/10.1016/j.quascirev.2020.106426, 2020.

Yang, Y., Chen, R., Song, Y., Liu, J., Han, C., and LIU, Z.: Measurement and estimation of grassland evapotranspiration in a mountainous region at the upper reach of Heihe River basin, China, Chinese Journal of Applied Ecology, 24, 1055-1062, https://doi.org/10.13287/j.1001-9332.2013.0280, 2013.

Yao, T., Wu, G., Xu, B., Wang, W., Gao, J., and An, B.: Asian water tower change and its impacts, Bulletin of Chinese Academy of Sciences, 34, 1203-1209, https://doi.org/10.16418/j.issn.10003045.2019.11.003, 2019a.

Yao, T., Thompson, L., Yang, W., Yu, W., Gao, Y., Guo, X., Yang, X., Duan, K., Zhao, H., Xu, B., Pu, J., Lu, A., Xiang, A., Kattel, D. B., and Joswiak, D.: Different glacier status with atmospheric circulations in Tibetan Plateau and surroundings, Nat. Clim. Chang., 2, 663-667, https://doi.org/10.1038/nclimate1580, 2012.

Yao, T., Xue, Y., Chen, D., Chen, F., Thompson, L., Cui, P., Koike, T., Lau, W. K.-M., Lettenmaier, D., Mosbrugger, V., Zhang, R., Xu, B., Dozier, J., Gillespie, T., Gu, Y., Kang, S., Piao, S., Sugimoto, S., Ueno, K., Wang, L., Wang, W., Zhang, F., Sheng, Y., Guo, W., Ailikun, Yang, X., Ma, Y., Shen, S. S. P., Su, Z., Chen, F., Liang, S., Liu, Y., Singh, V. P., Yang, K., Yang, D., Zhao, X., Qian, Y., Zhang, Y., and Li, Q.: Recent Third Pole's Rapid Warming Accompanies Cryospheric Melt and Water Cycle Intensification and Interactions between Monsoon and Environment: Multidisciplinary Approach with Observations, Modeling, and Analysis, Bull. Amer. Meteorol. Soc., 100, 423-444, https://doi.org/10.1175/BAMS-D-17-0057.1, 2019b.

Yao, T. D., Qin, D. H., Shen, Y. P., Zhao, L., Wang, N., and Lu, A.: Cryospheric changes and their impacts on regional water cycle and ecological conditions in the Qinghai Tibetan Plateau, Chinese Journal of Nature, 35, 179-186, https://doi.org/10.3969/j.issn.0253-9608.2013.03.004, 2013. 